\title{
NEGARA, ISLAM, DAN NASIONALISME SEBUAH PERSPEKTIF
}

\author{
Al Chaidar \\ Fakultas Ilmu Sosial dan Ilmu Pemerintahan (FISIP) \\ Universitas Malikussaleh Nangro Aceh Darussalam \\ Herdi Sahrasad \\ Pusat Studi Islam dan Kenegaraan (PSIK) \\ Sekolah Pasca Sarjana Universitas Paramadina, Jakarta. \\ Email: sahrasa@yahoo.com
}

\begin{abstract}
:
What happens with "Reformasi" (the Reform Movement/ Era)? After tha fall of Soeharto's New Order regime, Indonesia come into chaotic situation with many religious and ethnic conflicts. Separatism has erupted and corruption has been so rampant. The "door" of democracy opens, and both Islamists and nationalists take part in the political game. The results have been, however, transactional politics, bad governance and uncertainty. A question should be raiseed: is it irreconcilable between the nationalists and the islamists? What is happening when the political games are plyed by both parties is basically the competition of corruption. They are stealing "people resources and welth of the nation". Islamists do the same as the nationalists stealing power (corruption). The business world is corrupted. Businessmen are in collusion with politicians, rulers, and bureaucrats. They do not care anymore about the fate of the people and the country.
\end{abstract}

Keywords: State, Islam, Nationalism, new order, reformation, democracy, institution, conflict.

\begin{abstract}
ABSTRAK
Apa yang terjadi dengan "Reformasi" (Reformasi)? Setelah jatuh Orde Baru Soeharto, Indonesia masuk ke dalam situasi yang kacau dengan banyak konflik agama dan etnis. Sementara separatisme meletus dan korupsi begitu merajalela. Pintu demokrasi dibuka, baik Islamis dan nasionalis mengambil bagian dalam permainan politik, namun hasilnya adalah politik transaksional, pemerintahan yang buruk, dan ketidakpastian. Apakah itu menjadi tak terdamaikan antara nasionalis dan Islamis? Apa yang sedang terjadi adalah kompetisi korupsi dan mereka mencuri sumber daya manusia dan kekayaan bangsa ketika kesempatan itu dimainkan oleh kedua belah pihak. Kaum Islamis dalam pencurian kekuasaan (korupsi) merupakan kasus yang sama dengan kaum nasionalis. Bahkan dunia bisnis sangat korup dan rajin berkolusi dengan politisi, penguasa dan birokrat. Mereka tidak peduli lagi dengan nasib rakyat dan negara.
\end{abstract}

Kata kunci: negara, Islam, Nasionalisme, Orde Baru, reformasi, demokrasi, institusi, konflik 


\section{PENGANTAR}

Setelah gerakan reformasi Mei 1998 yang menurunkan Presiden Soeharto, perhatian dan komitmen rakyat terhadap sistem dan moral penyelenggaraan negara begitu besar. Namun, mayoritas rakyat kini merasakan bahwa masa depan bangsa kita justru memasuki era carut-marut dan ketidakpastian. Neoliberalisme, demokrasi liberal yang berwatak prosedural/kriminal dan korupsi yang merajalela di seluruh tubuh lembaga-lembaga negara: eksekutif, legislatif dan yudikatif, juga penegakan hukum (rule of law) yang buruk dan melemahnya masyarakat secara ekonomi dan sosial, makin menjontrongkan negara dan bangsa ke dalam ketidakpastian masa depan.

Tulisan ini merupakan esai dengan perspektif yang bersifat mosaik yang mencoba menganalisis negara dan masyarakat era Orde Baru Soeharto sampai Era Susilo Bambang Yudhoyono (Era Orde Reformasi), dengan telaah yang bertumpu pada kondisi obyektif dewasa ini setelah belasan tahun reformasi berlangsung. Lima belas tahun reformasi telah berjalan, yang terasakan adalah adanya keleluasaan sosial, kehidupan demokratis, kebebasan pers, kebebasan berpendapat di tengah-tengah sistem politik reformasi yang belum begitu kokoh menopang kehidupan perekonomian, mengangkat lemahnya kurs rupiah berfluktuasi terhadap mata uang asing (dollar).

Berbagai tuntutan keadilan yang disuarakan oleh berbagai kalangan, menyisakan pertanyaan-pertanyaan sejauh apa kita dapat mengatasi berbagai persoalan rumit secara lebih manusiawi. Makin terasa, lemahnya daya-tawar dari masyarakat madani (civil society) dalam upaya untuk menyelesaikan masalah sosial dan berbagai konflik yang terjadi di berbagai daerah dan di berbagai bidang kemanusiaan. Kaum nasionalis mengusung ideologi Nasionalisme dan kaum Muslim mengusung ideologi Islamisme (Tibbi, 2001; Roy, 1994).

Negara selama ini menghadirkan dirinya sebagai sosok yang mempunyai jaminan dan kuasa untuk menyelesaikan persoalan, dihadapkan pada kenyataan sosial seorang diri untuk mengatasi berbagai problema tersebut. Jika negara dikuasai oleh kalangan nasionalis, maka kalangan nasionalislah yang sendiri harus menyelesaikannya, kalangan Islam hanya menjadi oposisi loyal. Jika negara dikuasai oleh kalangan Islam, maka kalangan Islam sendiri sajalah yang harus menyelesaikannya. Jika negara dikuasai oleh pemerintahan nasionalis yang berkoalisi, maka terjadi banyaknya ketidaksinkronan antara elit-elit tersebut.

Apakah memang sudah tidak bisa dipersatukan antara kaum nasionalis dan kaum Islam? Yang terjadi justru proses persaingan korupsi dan mencuri kekayaan negara ketika kesempatan itu ada yang diperankan oleh keduabelah pihak. Kalangan Islam yang berkuasa mencuri (korupsi), pun demikian halnya dengan kalangan nasionalis. Bahkan dunia usaha pun sangat korup, dan getol berkolusi dengan politisi, penguasa dan elite birokrat Mereka seperti tidak peduli lagi dengan nasib rakyat dan negara ini.

\section{PEMBAHASAN \\ Negara, Islam, dan Reformasi: Era Ketegangan}

Setelah Orde Baru Soehartu runtuh, bisa dikatakan situasi era kepresidenan Habibie dan Gus Dur berada dalam fase transisional. Situasi ini ditandai dengan semakin "masifnya tegangan" di lembagalembaga negara: Eksekutif, Legislatif, dan Yudikatif dengan aroma konflik yang kuat. Kondisi ini ditambah berbagai macam persoalan rumit lainnya, yang kesemuanya adalah persoalan-persoalan yang belum terselesaikan sejak kejatuhan rezim Soeharto dengan Orde Barunya pada 21 Mei 1998. Tuntutan reformasi yang terus digulirkan sejak 1998 di berbagai sektor belum banyak menampakkan hasil, agar Indonesia segera keluar dari kemelut krisis. Berbagai upaya yang dilakukan oleh penguasa di era reformasi ini, belum sedikit pun membawa situasi ke arah yang lebih cerah.

Baik pemerintah maupun swasta belum merasakan dalam benak terdalamnya secara 
sadar akan esensi dari krisis yang tengah dihadapi. Sense of crisis penguasa seperti tidak ada. Indikasi kurangnya pemahaman sense of crisis dari kalangan pemerintah maupun dunia usaha. Pernyataan menteri dan pejabat tetap mengandung arti pesimisme. Selain makin membingungkan rakyat dan pelaku pasar, kadang juga menciptakan ketidakpercayaan pasar. Sikap penguasa ini bukan memperbaiki keadaan, tetapi justru ikut memperpanjang status quo yang mengidap potensial krisis dengan memperkeruh demokrasi liberal yang dibajak pemodal.

Pada era Gus Dur, melejitnya ketidakpercayaan pasar bukan lagi dari institusi perbankan dan birokrasi yang antikritik, tetapi birokrasi yang kontroversial. karena tidak ada tanda yang kuat dalam memperbaiki keadaan, pemerintahan Gus Dur sangat sulit menciptakan kebijaksanaan yang efektif. Visi reformasi ekonomi dan politik, karenanya, coba difokuskan pada penyelamatan darurat di sektor produksi dan ideologi serta perombakan besarbesaran undang-undang dasar. Perombakan UUD 1945 tidak hanya cukup mengganti preambule-nya dengan Piagam Jakarta yang menyiratkan kekerdilan politik Islam itu.

Namun satu hal yang juga berbahaya adalah bagaimana pemerintah dan swasta tidak lagi saling percaya. Pembicaraan dan imbauan IMF, selama ini terlalu santun untuk menyinggung reformasi total semacam pergantian ideologi, UUD dan kebijakan institusi. Apa pun saran IMF, yang perlu disadari adalah kenyataan bahwa perekonomian Indonesia tidak akan berkelanjutan tanpa perombakan/ pembaruan ideologi dan struktur institusional untuk menyelesaikan krisis yang terjadi. Masalah menguatnya dollar atas rupiah, yang tak terduga dan tak bisa diprediksi, menjadi berkepanjangan. Masalahnya, bukan hanya mengenai yang bersangkut paut dengan urusan mata uang asing, tetapi krisis moneter itu juga mengena seluruh lapisan masyarakat. Harga-harga bahan pokok yang tak ada kaitan dengan dollar, terus membumbung tinggi. Indonesia sepertinya harus mengganti mata uangnya dan membersih spekulasi mata-uang sebagai komoditas dalam perdagangan valuta asing.

Reaksi-reaksi yang muncul terhadap krisis ini, membuka kemungkinan terjadinya berbagai kemungkinan termasuk yang paling buruk sekalipun. Apa yang bisa diusulkan sebagai jalan keluar atau setidak-tidaknya kiat untuk survive? Pernyataan-pernyataan seperti krisis pasti akan berakhir memang ajakan yang simpatik. Walaupun batas harapan dan keputusasaan amatlah tipis, sehingga menghadapi keprihatinan, harapan dan keputusasaan itu sama-sama dengan gampang meletupkan perilaku kekerasan atau mendorong suasana panik. Kondisi psikologis ini semakin memprihatinkan, kalau lantas dimanfaatkan untuk kepentingan politik praktis yang sempit dan kepentingan ekonomis sepihak. Dalam konteks lebih luas, pengorbanan sebagai simbolisasi keprihatinan, mesti tidak terhenti pada ajakan. Krisis kepercayaan yang berkembang bisa sebagai akibat dari pra-kondisi yang terjadi sebelumnya.

Mengutip pernyataan Lester C. Thurow (2012) dalam the Future of Capitalism, keadaan ini ibarat kita dalam kondisi disequilibrium. Dalam keadaan demikian segala unsur masyarakat bergerak. Ketidakpastian, kecemasan, ketakutan berkembang luas. Sebaliknya kalau Thurow berpendapat keadaan ini adalah akibat sistem kapitalisme, hal yang kita hadapi belumlah jelas benar. Boleh jadi, Kapitalisme berwajah manusiawi yang lebih sosialistik mestilah segera diperkenalkan. Yang kita sepakati dengan Thurow ialah, keadaan tidak seimbang akhirnya akan menemukan keseimbangan baru; suatu keadaan yang tidak datang dengan sendirinya, melainkan harus diperjuangkan sekalian menuntut pengorbanan semua pihak.

Konsep disequilibrium menuju equilibrium baru, untuk menegaskan bahwa keseimbangan baru memerlukan upaya, konsep, langkah kerja yang jelas berikut keberanian untuk berkorban. Persoalan 
krisis moneter (baca: disequilibrium) coba diatasi dengan bantuan IMF berikut segala kesepakatannya. Ada kesatuan semangat dan langkah, bahwa demi kepentingan rakyat banyak, krisis harus segera diakhiri. Kalau lantas sampai hari ini krisis belum teratasi, artinya belum ditemukan equilibrium baru, seperti sudah dilihat banyak ahli halnya tidak sebatas pada persoalan ekonomi. Beberapa jalan keluar ditawarkan, antara lain reformasi ekonomi dan politik dilakukan secara konsisten dan transparan. Usulan dialog nasional mesti ditempatkan pula dalam konteks itu. Artinya, mempertemukan berbagai kesamaan dengan tujuan segera terbentuknya kesamaan derap sikap dan langkah demi masa depan bersama yang lebih baik. Kontrak sosial baru yang segera diwujudkan.

Negara-negara di Asia terperangkap dalam masalah kemiskinan, polusi dan kependudukan, tetapi dia merasa optimis dengan masa depan Asia. Optimisme Kenichi Ohmae dalam Year of Transition (Asiaweek, Desember 1997) justru membesarkan semangat bangsa Indonesia. Dia melihat, memang kemunduran ekonomi yang terjadi setelah terjadi krisis sebagai proses alamiah. Ketidaksamaan yang ada bisa diatasi antara lain dengan relokasi industri. Bagaimana, kapan dan bentuk berakhirnya krisis, niscaya menjadi permasalahan yang perlu didialogkan bersama. Ohmae (1997) itu menunjukkan bahwa krisis yang dialami sekarang bukanlah akhir segala-galanya. Bahwa krisis ini akan berakhir, bahwa badai pasti berlalu.

Krisis harus berakhir, tapi bagaimana cara mengatasi krisis mestilah menjadi komitmen bersama. Komitmen memang diawali dengan perasaan keprihatinan bersama. Tetapi ini belum cukup, sejauh belum ditemukan kesamaan persepsi, sikap, dan langkah untuk merealisir upaya mengatasi krisis. Syaratnya, seperti selalu dikemukakan banyak orang, yang diperlukan sekarang adalah kearifan; dan justru di saat-saat sekarang masyarakat sudah mengalami keprihatinan bersama, realisasi kearifan lebih besar "longgar-landung" itu sebagai keharusan mutlak sepanjang masyarakat ingin segera menyaksikan berakhirnya krisis dengan tetap dalam kerangka persatuan-kesatuan bangsa.

Di kalangan Muslim, reformasi dalam Islam menemukan padanan katanya sendiri dalam istilah yang sering kita dengar: mujaddid (reformer). Nabi Muhammad SAW adalah seorang mujaddid yang mengubah Negara Mekkah Jahiliyah menjadi Negara Islam (Negara Madinah) yang penuh dengan gemerlapnya peradaban dan terakuinya hakhak manusia. Apa yang telah dilakukan oleh Nabi Muhammad adalah suatu reformasi total terhadap sistem sosial, ekonomi, ideologi, politik, budaya dan militer. Tentu saja torehan sejarah ini memberikan bekas yang mendalam bagi pergulatan pemikiran politik umat manusia. Sebagai sebuah sistem (politik) yang bersifat partisipatif, yang mengesahkan persamaan hak di antara sesama manusia, maka demokrasi mungkin merupakan struktur "terbaik" yang pernah ada. Dan tidaklah mengherankan jika pengalaman dan eksperimen demokrasi di zaman Yunani kuno itu menjadi model ideal bagi para pemikir dan teoritikus politik di zaman modern ini. Padahal ada satu konsep lagi yang pantas dibahas idealitasnya bagi Indonesia masa depan, yaitu Negara Madinah.

Untuk memulai wacana tentang Negara Madinah ini, yang berbeda hampir 180 derajat dengan Negara Totaliter, maka perlu ada sedikit penjelasan teoritis tentang hal ini. Penulis melihat umat Islam Indonesia, melalui partai-partai politik Islam, ada baiknya perlu menelaah kembali substansi pemikiran Ibnu Khaldun (1332-1406) yang diakui otoritasnya baik sebagai pemikir tentang negara maupun sebagai ahli sejarah dan peletak dasar sosiologi. Bahkan sampai sekarang sarjana Barat mengagumi hasil-hasil pemikiran Ibnu Khaldu. Ia menulis dua buku yaitu: (1) Kitab al-'ibar (Kitab Ibarat-Ibarat) dan (2) Muqaddimah (Pengantar). Dalam bukunya, Muqaddimah, ia merumuskan teorinya tentang negara dan tipologinya (Noer, 1978: 51-52). 
Ibnu Khaldun menemukan suatu tipologi negara dengan tolak ukur kekuasaan (al mulk). Ia membagi negara menjadi dua kelompok yaitu (1) negara dengan ciri kekuasaan alamiah (mulk tabi'i) atau negara tradisional, dan (2) negara dengan ciri kekuasaan politik (mulk siyasi) atau negara modern. Tipe negara alamiah ditandai oleh kekuasaan yang sewenang-wenang dan otoriter (despotisme) dan cenderung kepada "hukum rimba". Di sini keunggulan dan kekuatan sangat berperan. Hukum hanya dipakai untuk menjerat leher rakyat yang tertindas, sementara elit penguasa bebas melakukan dosa dan maksiat sesukanya dan prinsip keadilan diabaikan. Baik keadilan ekonomi maupun keadilan sosial-politik. Ia menyebut negara alamiah seperti ini sebagai negara yang tidak berperadaban (uncivilized state).

Sementara itu, tipologi negara modern yang berdasarkan kekuasaan politik dibaginya menjadi tiga macam yaitu (1) negara hukum atau nomokrasi Islam (siyasah diniyah), (2) negara hukum sekuler (siyasah 'aqliyah), (3) negara "Republik" a la Plato (siyasah madaniyah) (Kerr, 1966: 29; Rosenthal, 1958 : 86). Negara hukum dalam tipe yang pertama adalah suatu negara yang menjadikan Syari'ah (hukum Islam) sebagai fondasinya. Malcolm H. Kerr, sebagimana dikutif oleh Thaher Azhary (Kerr, 1966: 29) menamakannnya dengan istilah Nomokrasi Islam (Islamic Nomocracy). Karakteristik Siyasah Diniyah atau Negara Hukum berdasarkan Islam menurut Ibnu Khaldun adalah negara yang berdasarkan $\mathrm{Al}$ Qur'an dan Sunnah, serta akal manusia yang turut juga berperan dan berfungsi dalam kehidupan negara. Akal manusia yang dimaksudkan adalah ijma' ulama dan qiyas. Sehingga Negara Nomokrasi Islam atau Negara Islam adalah Negara Ulama. Waqar Ahmad Husaini mencatat bahwa nomokrasi Islam bertujuan untuk mewujudkan kesejahteraan masyarakat universal, baik di dunia maupun di akhirat (al-masalih al kaffah). Husaini bahkan menggunakan istilah "Negara Syari'ah" untuk Siyasah Diniyah atau Nomokrasi Islam (Husaini, 1983 : 217232). Hal ini karena hukum di dalam Islam dikenal secara jurisprudensi sebagai Syari'ah.

Menurut Ibnu Khaldun tipe negara yang paling baik dan ideal di antara Siyasah diniyah, Siyasah 'aqliyah, dan Siyasah madaniyah ialah Siyasah diniyah atau nomokrasi Islam. Siyasah 'aqliyah hanya mendasarkan pada hukum sebagai hasil ratio manusia tanpa mengindahkan pada hukum yang bersumber dari wahyu, maka negara semacam ini dapat kita lihat pada negara-negara demokrasi Barat di Eropa maupun Amerika pada umumnya. Pada siyasah madaniyah (Republik ala Plato) merupakan suatu negara yang diperintah oleh segelintir golongan elite atas sebagian besar golongan budak yang tidak mempunyai hak pilih (Rosenthal, 1958 : 86).

Negara Madinah ini bisa kita lihat pada masa Demokrasi Terpimpin di bawah Soekarno (1959-1965). Sedangkan dalam pandangan Muslim skripturalis, archetype Negara Islam terbaik adalah konsep siyasah diniyah, yang pernah dan diproklamasikan oleh S.M. Kartosoewirjo adalah nomokrasi Islam berdasarkan konsepsi siyasah diniyah ini. Negara Diniyah inilah yang dicoba pertahankan oleh para pejuang dan syuhada Islam Indonesia di masa lalu, bukan Negara Otokratis yang notabene adalah Negara Sekuler atau dalam sebutan yang lebih emosional oleh kaum Muslim fundamentalis adalah Negara Syaitan. Dari ketiga tipe negara yang termasuk ke dalam bentuk mulk siyasah itu, maka secara teoritis Ibnu Khaldun lebih menyukai bentuk nomokrasi Islam atau dalam istilah siyasah diniyah sebagai "satusatunya bentuk tata politik dan kultural yang permanen" (Husaini, 1983 : 233).

Negara Islam seperti inilah yang menjadi cita-cita ideal seluruh umat manusia. Berdasarkan kerangka teoritis nomokrasi Islam (rechstaat) dari Ibnu Khaldun tentang siyasah diniyah yang merupakantipe ideal dari mulk siyasah, maka penegakan tentang Negara Hukum sudah waktunya untuk diperkuat kembali. Jika partai-partai politik Islam luput dengan perdebatan tentang hal ini, maka kehadirannya akan kehilangan signifikansi. 
Dan, lebih dai itu, secara ideologis partaipartai Islam tidak memihak sedikitpun pada Islam jika tidak mengemukakan konsep ala Negara Madinah ini dan implementasinya di Indonesia. Penulis menduga, tidak ada seorang tokoh partai politik Islam pun yang pernah mendengar tentang konsep Negara Diniyah atau Negara Madinah ini secara mendalam dan tuntas sebelumnya. Mengapa ? Karena dari banyak pernyataanpernyataan mereka, mengindikasikan bahwa mereka tidak punya wawasan sedikit pun tentang sistem kenegaraan. Kalau aspirasi dan suara umat diserahkan pada orangorang yang seperti tokoh-tokoh partai politik Islam sekarang ini, maka itu artinya sama dengan menyerahkan jiwa-raga kepada singa dan buaya. Maka, model pemimpin yang bagaimanakah yang bisa dimunculkan oleh tokoh-tokoh partai politik seperti itu?

Sehingga, sebagaimana terakui di dunia Barat sekalipun, kekuasaan Islam adalah lambang kemajuan yang sangat cemerlang dalam politik. Dalam Islam pengertian kekuasaan ini menjadi sesuatu yang inheren dalam ajaran-ajarannya yang diperoleh lewat suatu sosialisasi penyadaran dengan menggunakan Al Qur'an dan sejarah Nabi Muhammad SAW yang bermuara pada penaklukan kota Mekkah di bawah manajemen kekuasaan orde Islam. Kekuasaan, bukanlah sebuah kenikmatan yang harus dihirup, melainkan suatu tanggung-jawab maha berat yang harus dipikul dan mempertanggung-jawabkannya di hadapan Allah yang nota bene, secara demokrasi, adalah di hadapan rakyat banyak secara terbuka dan jujur. Berkuasa bukanlah memegang kendali politik sambil menikmati sumber daya dengan cara menindas, melainkan terkandung pertanggungjawaban politik yang berat di dalamnya.

Oleh karenanya, politik, sebagai salah satu aspek budaya Islam, berkembang dalam sebuah diskursus antara ketaqwaan (tunduk pada perintah atau kekuasaan suci, divine imperatives) dan praktek struktur kekuasaan. Menurut A.H. Johns, bagi Islam kekuasaan politik yang stabil ditandai oleh sebuah kepercayaan awal bahwa «masyarakat Muslim harus diperintah oleh Muslim yang terbaik». Persamaan moral seluruh pemeluk Islam dan perlunya mesyarakat diperintah menurut hukum Tuhan menjadi cita-cita bagi semua pemikir Islam, bagaimanapun sulitnya untuk menyesuaikannya dengan realitas politik yang ada (Reid, 1993: 12; Johns dalam Reid and Marr, 1981: 17-34). Bagaimanapun Islam telah melakukan suatu dekonstruksi dalam pengertiannya yang umum terhadap banyak premis pengetahuan yang berkembang selama ini (Cooler, 1983: 82-86).

Untukmenghindari salah pengertian dan phobi terhadap Islam, karakteristik negara Islam dipaparkan seorang cendekiawan Muslim sebagai berikut :

Pertama, Negara Islam adalah negara yang berakidah, yang dari sudut pembentukannya dan sebab keberadaannya, ia tegak di atas landasan falsafah yang lengkap. Yaitu atas landasan suatu akidah dan konsepsi wujud, falsafah etika yang memancar darinya yang mencakup sistem akhlak, hukum dan hubungan kemasyarakatan. Bukan sebagaimana yang digambarkan oleh sebagian orang yang mengacu pada pemikiran Barat, yaitu merupakan negara agama. Dalam arti hubungannya hanya terbatas pada suatu kepercayaan keagamaan yang bersifat gaib dan tata cara ibadah serta ritual-ritual semata (Al-Mubarak, 1995: 149-145).

Kedua, Janganlah melukiskan negara Islam dalam eksistensinya sebagai negara agama atau sipil dengan pengertian Barat (Eropa). Seseorang tidak bisa -dikarenakan jabatan keagamaannya- menafsirkan teksteks agama atau hukum. Sesungguhnya masalah bersama dimusyawarahkan dan dari kalangan putra-putra umat Islam harus mengkhususkan diri menguasai satu cabang ilmu. Bagi semua orang berhak melakukan dialog (diskusi) terhadap suatu persoalan dengan mengemukakan dalil dan hujjah.

Ketiga, Negara Islam adalah negara yang berakhlak dan berperi-kemanusiaan. Tujuan negara Islam tidaklah semata-mata 
mencari kekuasaan, memupuk kekayaan dan keagungan militer. Tujuannya tak lain hanyalah membebaskan manusia semuanya dari perbudakan, mengikatnya dengan ikatan yang lebih mulia, yaitu ketundukan kepada Allah saja serta menegakkan keadilan di antara umat manusia seluruhnya. Karena itu, tujuan akhlak manusia didahulukan daripada tujuan-tujuan ekonomi, politik dan militer di dalam negara Islam. Dengan begitu, ia berbeda-beda dengan negara-negara yang tujuan utamanya adalah memperbanyak produksi atau memperluas pengaruh (dominasi) dan kekuasaan. Di dalam Negara Islam yang dibayangkan Ibnu Khaldun ini, semua hanya tunduk pada kriteria-kriteria dan nilai-nilai akhlak.

Keempat, Negara Islam adalah negara berperadaban. Negara Islam tidak hanya membatasi diri dalam tugas-tugasnya menjaga keamanan dan melindungi wilayahnya dari agresi. Namun lebih dari itu, ia berkepentingan pada tujuan-tujuan yang bersifat positif dan pengarahan di lapangan perekonomian, ilmu pengetahuan dan seluruh perlengkapan yang memberi kemanfaatan kepada orang banyak secara umum. Diperluas bidang-bidang kegiatan buat masyarakat dalam batas-batas tujuantujuan kemanusian dan akhlak dalam Islam.

Kelima, Negara Islam kokoh dasarnya dan berkembang bentuknya. Selain daripada itu, yang berupa rincian-rincian dan aturanaturan, diserahkan kepada ijtihad dan pemikiran manusia serta perubahan bilamana situasi menghendaki hal itu. Dengan begitu, negara Islam menerima bentuk-bentuk negara, sesuai dengan perbedaan kondisi dan perubahan tingkatan masyarakat yang silih berganti.

Apa artinya sebuah bangsa jika dari waktu ke waktu hanya jatuh dari tangan zalim yang satu kepada tangan zalim yang lain? Dalam persepsi kalangan politik Islam, bangsa Indonesia, telah keluar dari mulut harimaudanuntukkemudian masukkemulut buaya. Kekuatan umat Islam merupakan satu-satunya kekuatan yang mampu menjadi anasir kontrol terhadap lembaga kekuasaan yang mapan. Perjuangan umat Islam, baik di lini milisia maupun intelektual, juga lini kooperasi maupun non-kooperasi telah demikian mewarnai perjalanan pengalaman politik Indonesia. Jika tidak ada suatu kaum yang menyeru kepada kebaikan, maka tidak mungkin bangsa ini akan berubah nasibnya. Maka, kalangan politik Islam, mengartikan gerakannya sebagai satu-satunya gerakan yang menyeru kepada yang ma'ruf dan mencegah yang munkar. Dalam persepsi Kalangan politik Islam mereka sudah menjadi umat Islam satu-satunya, dan merupakan ayatun bayyinat dari Al-Qur'an, Ali 'Imran 104 dan 110. Sementara kaum atau umat di republik dianggap "Mereka satu sama lain selalu tidak melarang mereka dari mengerjakan yang munkar" (Al-Qur'an, AlA'raaf 175) atau "Mereka (kaum republik) menyuruh membuat yang munkar dan melarang berbuat yang makruf.." (QS. atTaubah: 67).

Perlu kiranya kita memahami konstelasi gerakan kalangan politik Islam dari sudut psikologi umat dalam menatap realitas hidup dengan kacamata keagamaan. Sesungguhnya ada raison d'etre yang menjadi alasan bagi munculnya reaksi politik secara kekerasan dari umat Islam. Dengan melihat doktrin karakteristik mereka untuk menegakkan sistem otoritas, yaitu melalui kepemimpinan dengan hirarki yang ketat, kita dapat menyimpulkan gerakan ini timbul sebagai reaksi terhadap proses marjinalisasi dan atomisasi kehidupan modern. Secara psikologis mereka merasa kehilangan pegangan dalam menghadapi proses sosial yang baru pasca kemerdekaan.

Disampingitu,merekainibiasanyaadalah kelompok-kelompok yang tak terjangkau oleh kepemimpinan organisasi umat yang ada. Keorganisasian Islam hanya bergerak pada jalur-jalur formal dan seremonial saja. Yang kemudian menjadi menarik adalah, kelompok semacam ini muncul baik di daerah pedesaan maupun di daerah urban. Berlainan dengan gerakan-gerakan sempalan Islam (Kuntowidjojo, 1991: 204) yang muncul akhir-akhir ini yang tidak memiliki idealisme 
politik yang hanya kritis pada permukaan realitas sosial tapi tidak bisa menarik akar penyebabnya secara struktural, gerakan Kalangan politik Islam senantiasa bergerak dengan idealime yang sarat dengan muatan politik. Bahkan, jika kita melihat proses dan tahap pemahaman tauhid mereka (kalangan politik Islam), hampir semua ajaran Islam adalah ajaran politik: agama adalah politik.

Agama sering menjadi obyek kompensasi, pelarian dari tidak pernah pupusnya cobaan hidup. Kontrasnya dengan pengikut Kalangan politik Islam adalah pengikutnya yang ikut bukan karena ingin berlindung dari ujian hidup yang semakin menghunjam, melainkan karena kesadaran kolektif umat untuk mengadakan kontrol terhadap kekuasaan. Bahkan, kekuasaan yang sedang dipegang oleh penguasa republik, negara boneka Pasundan, maupun kolonial, adalah tidak sah (Suseno, 1987). Legitimasi kekuasaan hanya sah jika disetujui oleh mayoritas Islam. Makanya, pengikut gerakan Kalangan politik Islam tidak memiliki kebutuhan internal untuk berlindung dari proses sosial di luar mereka. Justru kalangan politik Islam sudah baro'ah (berlepas diri) dari kehidupan sosial karena sikap politik hijrah yang benar-benar konsisten. Dan, gerakan kalangan politik Islam bukanlah paguyuban di mana jamaah-nya atau pengikutnya tidak perlu mencari-cari kembali identitas kolektif mereka yang hilang.

Yang menarik pada gerakan politik Islam adalah rasa aqidah mereka yang tidak merasa kehilangan diri mereka sendiri, kehilangan kebebasan pribadi karena begitu tergantung pada guru atau pemimpin mereka. Rasa kebersamaan dalam satu -mengutip istilahnya James Siegel- tali ikatan Tuhan untuk meruntuhkan kekuasaan yang zalim telah menyerap kebebasan pribadi mereka. Biasanya juga, mereka menjadi radikal karena kecewa terhadap ulama-ulama atau pemimpin-pemimpin umat yang tidak peka terhadap kenyataan sosial dan politik. Ulama atau kiyai yang cenderung mendukung penguasa, di mata mereka adalah ulama ahli-kitab yang "dipandang tidak beragama sebelum menegakkan ajaran-ajaran kitab suci" (QS. Al-Maidah 5: 68). Mereka membina tradisi yang bersifat politik yang cenderung berbau kekerasan dan wajar sekali jika kemudian mereka melihat Indonesia ini dikuasai oleh persona yang mewakili profil Fir'aun. Untuk menghadapi Fir'aun itu mereka melakukan dengan jalan qital (jihad bersenjata atau kekerasan) dan ghazwul fikri (perang pola pikir). Dua modus yang menggabungkan semua strategi untuk mencapai kemenangan.

Kekerasan adalah suatu kecenderungan yang membawa mereka ke arah gerakan anarkhis. Orang-orang yang frustrasi karena alasan-alasan sosial ekonomi, akan menjadi kekiri-kirian, sementara yang frustrasi karena alasan-alasan keagamaan cenderung menjadi ke kanan-kananan. Namun “golongan kanan" dalam kitab suci Quran jauh lebih mulia daripada cap ekstrim kanan oleh pemerintah karena "kekerasan religius" yang mereka lakukan. Lihat misalnya, "Alangkah mulianya golongan kanan itu" (QS. Al-Waqi'ah: 8) dan "Alangkah bahagianya golongan kanan itu" (Al-Qur'an, Al-Waqi'ah 27), "Mereka (orang-orang yang Al-Balad 18), "maka keselamatan bagimu karena kamu dari golongan kanan" (QS. AlWaqi'ah: 91).

Hubungan krusial antara negara (state) dengan umat Islam seperti ini, pada bagian lain, sebagaimana umumnya pemerintahan yang "zalim", pemerintah terlalu membesar-besarkan Islam sebagai suatu ancaman. Pemberontakan Kalangan politik Islam yang bisa dipatahkan dijadikan preseden negatif yang selalu dibesar-besarkan untuk mendukung legitimasi rezim penguasa dengan cara menggambarkan Islam sebagai ancaman bagi kesatuan nasional. Pemerintahan yang zalim selalu menindas segolongan dari rakyatnya untuk memperkuat basis legitimasi kekuasaannya. Jika penindasan ini kendur, maka legitimasinya juga melemah. Akibatnya pemerintah pun melakukan depolitisasi dan deideologisasi Islam secara nasional. Politik yang berlabel etnis, agama, 
regionalisme dan afiliasi golongan dianggap sebagai sumber disintegrasi bangsa.

\section{Konstitusi dan Pemerintahan: Islam dan Nasionalis}

Mereka-mereka yang duduk dalam pemerintahan mesti bertindak sebagai wakil dari para pendukungnya (constituents). Mewakili berarti hadir atas nama orangorang lain yang tidak bisa berhadir. Pemilu, tentunya, bukanlah satu-satunya cara untuk mengamankanketerwakilanataumemastikan keterwakilan suatu pemerintahan. Raja-raja yang memerintah secara turun-temurun di abad Pertengahan, menganggap dirinya sebagai perwakilan masyarakatnya. Hanya Rousseau, teoritikus Kontrak Sosial, menolak kelayakan perwakilan bagi kegunaankegunaan legislasi. Status orang-orang yang duduk dalam pemerintahan terkadang dianggap tak mempunyai jaminan bahwa mereka akan "secara eksistensial mewakili" konstituen mereka, hingga mereka berbagi karakteristik vital seperti ras, agama, jenis kelamin, atau umur.

Persoalan perwakilan dalam kenyataannya sangat dekat hubungannya dengan demokrasi daripada dengan kriteria pemerintahan konstitusional: suatu rejim yang dianggap tidak representatif oleh standard-standar modern tetap masih diangga konstitusional sepanjang pemerintahan tersebut memberikan stabilitas prosedural dan pertanggungjawaban kepada sebagian besar yang diperintah dan sejauh pemerintah itu representatif bagian sebagian besar masyarakat atau badan politik. Menurut Roger Garaudy (1982), sistem perwakilan (parlementer) merupakan bentuk sistem pemerintahan yang dilahirkan dan kondisi sejarah yang khusus hanya untuk Inggris dan Perancis. Sistem ini diekspor ke negaranegara yang struktur dan kebudayaannya berbeda. Pencangkokan ini akhirnya menyebabkan umat Islam menjadi asing dari dirinya sendiri, dari teman-temannya, dari sejarahnya, dari kebudayaannya dan dari hari esoknya sendiri. Modernitas yang diusulkan selama ini kepada umat Islam untuk membangun negara dan dirinya berarti untuk melalui kembali tahap-tahap yang dilalui oleh Barat selama empat ratus tahun. Ini berarti bahwa umat Islam harus menganggap masa lalunya orang lain (Barat) sebagai hari esoknya sendiri.

Akbar S. Ahmed (1993: 47-48) melihat bahwa periode modern ini telah menggiring kaum Muslim ke arah jalan kebuntuan. Diktator, kudeta, korupsi dan nepotismedlam politik; standar pendidikan yang rendah; paresis intelektual; penindasan terhadap wanita, dan distribusi kekayaan yang tidak adil, menjadi sebagian karakteristiknya. Perusahaan-perusahaan multinasional dan kegiatan mereka yang nyata-nyata mendukung elite lokal yang korup, migrasi besar-besaran dari wilayah pedesaan ke perkotaan, dan sebagai akibatnya gangguan sosial dalam kehidupan tradisional, dan kegagalan membangun institusi-institusi negara modern yang efektif, adalah sebagian karakteristik lainnya.

Persoalan khususnya bagi krisis multidimensional di Indonesia, Tisnaya Kartakusuma menilai, bahwa Naskah UUD 1945 adalah sumber dari segala sumber kegagalan kronis bagi setiap rezim politik di Indonesia -dari rezim Soekarno, Soeharto, Habibie, dan Wahid/Megawati- dalam melaksanakan tiga (3) paradigma klasik: supremasi hukum, kedaulatan rakyat dan kesejahteraan rakyat (Kartakusuma, 2001). Menurutnya, tidak ada Indonesia baru dengan konstitusi baru, dan tidak ada Indonesia baru tanpa konstitusi baru.

Pada saat para perintis kemerdekaan (generasi 1945) dalam merumuskan naskah UUD 1945 dalam kondisi yang tidak sempat berfikir panjang dan telaten (serius) untuk membuat suatu naskah "UUD" baru atau "Konstitusi Baru" sebagaimana diamanatkan oleh Pasal 3 UUD 1945, bukan karena soal kemampuan intelektual, tetapi karena keadaan darurat dan memaksa menjalankan Perang Kemerdekaan melawan penjajah asing yang sedang dihadapi oleh seluruh Bangsa Indonesia dengan fokus perhatian untuk mempertahankan Proklamasi 
Kemerdekaan Indonesia 17 Agustus 1945 [1945-1949], keselamatan hidup kemerdekaan Bangsa-Negara Indonesia yang baru lahir, dibandingkan dengan persoalan bagaimanakah harus memikirkan atau merumuskan konsep "perubahan" naskah UUD 1945. Barulah pada tahun 1950, generasi 1945 perumus naskah UUD 1945 itu berhasil merancang, membangun dan merumuskan suatu "Konstitusi Baru Sementara", yang diberi nama, yakni "UUD Sementara" [UUDS], walaupun tanpa melalui prosedur demokratis, yaitu suatu "Pemilihan Umum" (Kartakusuma, 2001).

Akan tetapi, dinamika praktek sistem politik parlementer UUDS 1950 selama periode 1950-1959, memuncak menjadi suatu krisis politik dan konstitusional. Karena menghadapi keadaan krisis demikian, apalagi dengan serangkaian pemberontakan daerah dan kegagalan Dewan Konstituante merancang "Konstitusi Baru", Presiden Soekarno telah menerbitkan "Dekrit 7 Juli 1959" untuk memberlakukan kembali naskah UUD 1945 di Indonesia. Setelah ini, motivasi elite Generasi 1945 mengalami pergeseran fokus perhatian ketatanegaraan, yaitu adalah lebih menonjol bagaimana kalangan elite Perintis dan Pejuang Generasi 1945 dapat tetap "mempertahankan UUD 1945" demi melanggengkan kekuasaan politik dan kenegaraan di Indonesia.

Pada masa selanjutnya, gaya ini diadopsi oleh Rezim Orde Baru/Soeharto dalam mengendalikan kekuasaan di Indonesia. Rezim Soeharto melaksanakan proses "sakralisasi naskah UUD 1945" dan menetapkan "Pancasila" sebagai ideologi tertutup di dalam konteks masa jangka panjang, yang mengatur secara otoriter semua sendir kehidupan ketatanegaraan, perekonomian dan menguasai budaya, sosial, politik di Indonesia selama lebih kurang 32 tahun secara berkelanjutan [1966-1998]. Hingga masa transisi reformasi yang sedang berjalan, dari masa pemerintahan transisi reformasi Habibie hingga Wahid/Megawati dan Susilo Bambang Yudhoyono, persoalan konstitusi belum selesai diamandemenkan demi memperoleh masa depan Indonesia secara baik.

Nasionalisme politik di Indonesia diperkenalkan oleh para intelektual dan kaum terpelajar yang pada awal abad 20 membentuk Boedi Oetomo (1908). Gerakan ini berkembang di kalangan terpelajar yang kelak menjadi cikal-bakal terbentuknya elite modern Indonesia, yang oleh Robert van Niel diuraikan sebagai berasal dari kaum priyayi. Kebangkitan nasionalisme yang dipelopori kaum terpelajar itu, antara lain Wahidin Soedirohusodo, Sutomo, HOS Tjokroaminoto dan generasi yang lebih muda seperti Soekarno, Hatta, Sjahrir, SM Kartosoewirjo, Tan Malaka, dan lain-lain, semakin mendinamisasikan kaum pergerakan dalam upaya mencapai kemerdekaan. Di bawah cengkeraman kolonialis Hindia-Belanda dan juga Jepang, para tokoh pergerakan itu menyadari benar arti penting semangat nasionalisme. Para penjajahyang menerapkan kapitalisme modern itu telah mengakibatkan bangsa Indonesia sangat menderita dengan kemiskinan, kebodohan dan kesengsaraan. Sebab kapitalisme modern menerapkan dominasi di bidang politik, eksploitasi di bidang ekonomi dan penetrasi di bidang kebudayaan. Maka dari itu nasionalisme Indonesia adalah nasionalisme yang anti kapitalisme (van Niel, 1984).

Pahlawan pendidikan kita Ki Hajar Dewantara mengemukakan rasa kebangsaan yang berasal dari rasa percaya diri, yang menjadi rasa kekeluargaan dan menjadi rasa hidup bersama. Kemudian mewujudkan untuk mempersatukan kepentingan bangsa dengan berkepentingan sendiri, nasib bangsa dirasakan sebagai nasibnya sendiri, kehormatan bangsa sebagai kehormatan sendiri (Sopingi, 1999: 70). Sedangkan Ir Soekarno(Presiden Pertama RI), menegaskan, bangsa adalah kelompok manusia yang mempunyai hasrat untuk bersatu teguh, mempunyai kesatuan sifat yang umum dan tinggal di atas wilayah geopolitik yang nyata merupakan satu persatuan. Jadi kesatuan sifat atau disebut watak nasional, yaitu 
sejumlah ciri-ciri atau watak nasional yang membedakan rakyat suatu bangsa dengan bangsa lain (Feith and Castles, 1988).

Bangsa tidak terbatas pada persamaan keturunan-ras atau persamaan agama. Tetapi mereka mempunyai persamaan hidup dalam satu wilayah tertentu, seperti halnya bangsa Indonesia yang terdiri dari berbagai suku bangsa, bahasa daerah, agama dan adat istiadat, namun bertekad satu seperti tercermin dalam motto Bhinneka Tunggal Ika. Bersatu dalam satu kesatuan yang kokoh dan kuat, di dalam satu naungan negara kesatuan Republik Indonesia yang diproklamasikan pada tanggal 17 Agustus 1945. Dan sebagai landasan yang kokoh kuat tersebut adalah dasar negara Pancasila. Soekarno menegaskan Pancasila juga merupakan ideologi nasional yang menjiwai semangat persatuan bangsa Indonesia yang majemuk (Feith and Castles, 1988). Namun semangat zaman di era cyber space sekarang ini, persoalan-persoalan bangsa sekarang lebih menuntut jawaban negara untuk memberikan alasan-alasan baru untuk bersatu. Mungkin alasan baru yang pernah dikemukakan Anthony Giddens tentang "the third way" layak kita pertimbangkan.

Di bawah era Presiden BJ Habibie, Abdurrahman Wahid, Megawati dan Susilo Bambang Yudhoyono, ternyata gagasan "jalan ketiga" Anthony Giddens sempat menjadi wacana (discourse) yang memikat kalangan kaum pro demokrasi, kalangan santri dan aktivis Islam. Politik "jalan ketiga" adalah representasi dari pembaharuan demokrasi sosial. Politik "jalan ketiga", demikian Giddens, diperlukan karena masalah-masalah yang berkaitan dengan perbedaan antara garis kiri dan garis kanan dalam politik sudah begitu besar. Saat ini pandangan (mengenai dunia) dari elite kiri yang lama sudah tidak bisa dipakai lagi. Sementara pandangan kanan yang baru juga tidak memadai karena mengandung banyak kontradiksi.

Pandangan politik aliran tengah sendiri juga telah menjadi begitu radikal hingga tidak lagi mampu menampung politik kiri maupun kanan. Diperlukan sebuah wahana baru untuk menampung kiri moderat (hasil pembaruan kanan) dan kiri tengah (hasil pembaruan kiri) agar politik emansipatoris dan keadilan sosial tetap menjadi pusat perhatian. Menanggapi gagasan brilian Giddens dalam konteks masyarakat Barat itu, Profesor Chibli Mallat, ahli politik Lebanon, mengatakan konsepsi "jalan ketiga" Anthony Giddens sebagai konsepsi politik yang baru. Namun Giddens dinilai telah mengabaikan negaranegara non-Barat, khususnya negara-negara Muslim. Sejak dasawarsa 1970-an dan 1980an, slogan «jalan ketiga» Giddens itu sudah berkumandang di negara-negara Muslim. Revolusi Iran-lah yang mencanangkannya dengan menegaskan bahwa «jalan ketiga» adalah Islam, yang sistem kemasyarakatan bukan model Barat (kanan) atau model Soviet (kiri), tidak Blok Barat maupun Blok Timur (la syarqiyah la gharbiyah). Profesor Mallat mencatat, dalam sejarah abad ke-XX, "jalan ketiga" adalah namalain dari NazismeJerman dan Fasisme Italia, yang mencoba memberi alternatif baru terhadap ideologi komunisme (Uni Soviet) dan kapitalisme (AS). Mallat kemudian mengusulkan agar para penganut “jalan ketiga" lebih menekankan nilai-nilai peradaban yang mampu menghilangkan berbagai ketimpangan struktural.

Dengan menyimak gagasan Giddens dan tanggapan Mallat itu, ada baiknya para inteligensia Muslim dan nasionalis kini harus mencermati "jalan ketiga" yang kontekstual dengan Indonesia, di mana pluralitas (kemajemukan) sangatlah sarat kompleksitas. Tentang Islam dalam hubungannya dengan "jalan ketiga" Giddens itu, penulis ingin meminjam diskursus Bernard Lewis yang menyatakan bahwa Islam yang lebih awal di era Cordova Spanyol, sangatlah toleran. Di Indonesia Islam yang lebih awal itu datang dengan jalan damai melalui perdagangan. Dan sebagaimana di zaman Islam Cordova Spanyol, di Indonesia pun Islam awal ini ternyata cenderung lebih toleran dibanding Islam yang lebih belakangan. Pada masa Islam awal itu, banyak pergaulan sosial yang berlangsung dengan lancar antara 
kaum Muslim, Kristen, Hindu, Buddha dan Cina. Meskipun menganut agamaagama yang berbeda, mereka membentuk sebuah masyarakat yang beradab, di mana perkawanan antarpribadi, kemitraan dalam bisnis, hubungan guru-murid dalam kehidupan ilmu pengetahuan, dan bentukbentuk lain kegiatan bersama berlangsung normal dan bahkan sangat umum.

Kerja sama kultural ini, seperti dicatat Anthony Reid, tampak dalam banyak cara orang-orang Islam, Hindu-Budha dan Kristen menjalankan kehidupan dan kebudayaan. Bahkan di era pergerakan nasional untuk mewujudkan kemerdekaan, kaum pluralis ini berjuang dalam spirit Sumpah Pemuda. Dan sampai era demokrasi parlementer Bung Karno pada 1950-an, kaum Muslim dan non-Muslim itu hidup dalam suasana penuh peradaban, saling hormat, dan saling mengembangkan ilmu pengetahuan dan seni budaya. Tidak ada sedikit pun diskriminasi, karena pembangunan bangsa dan karakternya (nation and character building) berjalan wajar. Karenaitu, masalah pluralisme adalah masalah bagaimana kaum Muslim mengadaptasikan diri mereka dengan dunia modern, yang sampai kurun 1950an itu dijamin oleh konstitusi. Pada kurun waktu itu Islam menghormati pluralitas dan menghargai kultur masyarakat yang ada. Semangat pluralisme dikembangkan dan toleransi ditegakkan dengan kasanah intelektual yang diperkaya.

Akan tetapi, di bawah Orde Baru Soeharto,semua itu mengalami keretakan: state building (pembangunan negara) telah melebihi dan menghancurkan nation building (pembangunan bangsa). Negara kian represif dan hegemonik, melibas masyarakat di seluruh etnis, kelas, dan lapisan. Politik belah bambu dan regimentasi Orde Baru Soeharto meluluhlantakkan spirit kebangsaan dan kemanusiaan. Karena itu, para intelektual dan elite Islam harus mencari jalan keluar dari krisis-krisis sosial,ekonomi, politik dan ideologi dewasa ini, agar reformasi tidak mengalami stagnasi, agar bangsa ini tidak mengalami disintegrasi. Giddens menyebut politik "jalan ketiga" dengan menekankan "tak ada hak tanpa tanggung jawab". Di dalam Islam era Rasululah, "tak ada hak tanpa tanggung jawab" itu teraksentuasikan dalam Piagam Madinah, yang menjamin kebebasan, persamaan dan keadilan. Di era Islam Cordova, Spanyol, spirit dan konsepsi "Piagam Madinah" itu kemudian menjadikan mereka komunitas yang pluralistik, kosmopolit dan universal, sehingga mereka bersedia belajar dan menerima segala yang bernilai dari pengalaman-pengalaman komunitas lain.

Dalam konteks Indonesia era reformasi (dari era Habibie,Gus Dur, Megawati sampai Presiden Susilo Bambang Yudhoyono) ini, selain sumber non-Islam, maka Islam seyogyanya menjadi sumber inspirasi dan nilai untuk membentuk good governance dan supremasi hukum, yang merupakan suatu keharusan. Ini signifikan untuk mewujudkan apa yang disebut Anthony Giddens sebagai politik "jalan ketiga", yang menekankan nilai-nilai peradaban untuk menghapuskan struktur ketimpangan. Tegaknya negara hukum dan terwujudnya good governance ini akan melandasi tegaknya demokrasi, politik emansipatoris dan keadilan sosial guna menjamin pluralitas (kemajemukan) yang kini dalam kerawanan.

Modernisasi Orde Baru sampai era transisi dewasa ini, telah menimbulkan transformasi sosial-budaya, ekonomi dan politik Indonesia, yang secara struktural merubah orientasi politik kalangan Islam Indonesia . Di era orde reformasi dewasa ini, transformasiitu tungganglanggang (runaway) di antara developmentalisme (kapitalisme), demokrasi, kebangsaan, keislaman dan keadilan. Perubahan-perubahan orientasi politik masa Islam bukanlah semata-mata didorong oleh reinterpretasi terhadap ajaranajaran itu sendiri, melainkan juga dipercepat oleh perubahan struktural seperti yang diindikasikan dengan lahirnya ICMI (Ikatan Cendekiawan Muslim se-Indonesia) dan reaksi keras terhadapnya. Dalam konteks ini, meminjam diskursus William Liddle, Islam kultural justru berkembang di Indonesia tanpa terlibat di dalam politik praktis yang 
sarat korupsi. Karenanya, umat Islam telah dapat bergerak dalam segala aktifitas sosialbudaya dan keagamaannya tanpa harus berhadapan dengan hambatan-hambatan serius seperti yang ditemuinya di masa lalu.

Pembangunan Orde Baru telah mendorong tingkat mobilisasi sosial-budaya yang lebih tinggi. Ini karena prasarana transportasi publik yang lebih murah, perbaikan prasarana jalan dan rel serta komunikasi terus berkembang. Semua ini meningkatkan akses masyarakat ke kota-kota besar. Isolasi relatif masyarakat desa terkuak dengan tersedianya radio-radio murah dan meningkatnya akses terhadap televisi. Dan, bagi perluasan cakrawala intelektual, perkembangan media cetak di masa Orde Baru telah sangat membantu memberikan dasar-dasar bagi perkembangan lebih lanjut. Semua ini adalah akomodasi non-politik yang kemudian, lambat laun, akan memberi perubahan pada daya tawar-menawar (bargaining power) rakyat terhadap penguasa. Maka, pintu gerbang bagi terciptanya akomodasi politik pun terpaksa terkuak karena Soeharto sendiri tidak lagi memiliki cengkeraman pengaruh di kalangan ABRI/ TNI.

Akomodasi politik Islam merupakan petunjuk perubahan persepsi diri di kalangan umat Islam. Maka dalam konteks ini, Islam yang tadinya berkembang biak tanpa politik, tiba-tiba mengalami perubahan-perubahan struktural yang sangat besar pengaruhnya terhadap umat Islam Indonesia. Didukung oleh lapisan-lapisan petani, pedagang menengah dan beberapa kalangan yang telah berada dalam posisi white collar job, mereka, di awal Orde Baru, gagal menangkap kembali pengaruh terbatas yang bahkan pada 1950-an hanya sekali-kali dinikmatinya. Kehidupan politik dunia usaha di awal Orde Baru telah terkonsolidasikan ke dalam Kamar Dagang dan Industri (Kadin), suatu organisasi bisnis yang menikmati dukungan finansial dari pemerintah yang, sebagai akibatnya, menjadi saluran komunikasi utama antara masyarakat bisnis dengan pemerintah. Sebagai salah satu ciptaan Orde Baru, Kadin didominasi oleh kalangan bisnis yang tumbuh dari dan di dalam aparatur Negara -terutama pada awal-awal tahun pembentukannya- daripada kaum menengah Muslim.

Kenyataan baru ini menyentak kesadaran umat, terutama ketika mereka semakin menyadari betapa kecilnya peran politik mereka dalam proses restrukturisasi sosial-ekonomi dan politik di dalam percaturan politik di masa Orde Baru. Maka keutuhan dan kesetiaan lama - sebagaimana tercermin pada politik aliran-tidak bisa dipertahankan lagi. Perubahan situasi yang radikal itu, karenanya, haruslah dipahami dengan akidah yang baru. Pergeseran kesadaran ini telah menggoyahkan pendapat yang pernah secara teguh hidup dan berkembang di kalangan umat Islam: bahwa negara Islam bukanlah alat tunggal untuk mewujudkan cita-cita ajaran Islam di muka bumi. Pada gilirannya, pergeseran pemikiran ini pula yang mendorong berbagai kelompok sosial di kalangan umat mereformulasikan keberadaan dan ideologi yang diyakininya. Harus diakui, di kalangan Islam skripturalis, impian akan Negara Madinah (Islam) sajalah satu-satunya alat politik perjuangan untuk menegakkan hukum-hukum Allah. Partai pun diharuskan menuju ke Negara Madinah (Islam), agar mendapat kepercayaan rakyat.

Namun, diimbangi dengan kegagalan yang berulang-ulang di dalam kancah politik Orde Baru, yang melahirkan frustrasi di kalangan Islam, sisa-sisa kepemimpinan politik Islam di masa lalu itu semakin melemah di dalam ruang lingkup Orde Transisi BJ Habibie dan Orde Reformasi era Presiden Abdurrahman Wahid, Megawati dan Susilo Bambang Yudhoyono dewasa ini. Tahun-tahun terakhir perkembangan Islam Indonesia menyaksikan kemerosotan pengaruh kaum ideologis itu. Pengaruh tokoh-tokoh partai politik Islam di masa lampau, kendati masih tetap dihormati, dengan sempurna telah terkosongkan dari ruang kesadaran politik umat -terutama di kalangan mereka yang telah terurbanisasikan. Di sinilah gagasan negara Islam secara tajam telah merosot. Kemenangan Golkar yang 
berulang-ulang di dalam setiap pemilu masa Orde Baru dan juga dalam pemilu Orde Reformasi -kendatipun bukan tanpa kecaman- secara mencolok menunjukkan betapa intensifnya perubahan-perubahan ideologis di kalangan umat. Terlebih jika mengingat bahwa kemenangan-kemenangan Golkar itu justru terjadi di daerah-daerah yang sebelumnya menjadi pendukung konvensional partai-partai Islam.

Dengan melihat merosotnya gagasan negara Islam itu, ummat kehilangan impian tentang Negara Madinah yang pernah dibayangkan (imagined state). Namun, pada 1997/98 terjadi krisis ekonomi, politik dan sosial sehingga ada peluang di era reformasi untuk mengajukan model "negara keadilan" yang dibayangkan ummat Islam, dengan tafsir baru yang kontekstual. Maka, sudah waktunya para intelektual dan politikus Islam melakukan pencarian untuk membuka wacana Negara Madinah era Rasululah yang dibayangkan. Bagaimanapun, konstitusi dan undang-undang Republik Indonesia yang ada, belum menjamin supremasi hukum, politik emansipatoris dan keadilan sosial sehingga perlu penyempurnaan atau amandemen.

Dalam situasi pancaroba dewasa ini, berbagai kalangan Islam masih meyakini bahwa Piagam Madinah dan praktik pemerintahan era Rasululah SAW dan empat khalifah pendahulu, sangat mungkin untuk dimanfaatkan sebagai sumber nilai dan inspirasi bagi hukum dan perundangundangan di Indonesia. Selain akan membuat hubungan para intelektual dan politikus Islam kian mengakar dengan ummat, hal itu juga akan mencegah kemungkinan timbulnya apa yang disebut Gustave le Bon (2000) sebagai revolusi religius atau bahkan, anarkisme religius. Lagipula konstitusi dan undang-undang yang ada akan kian diperkaya, disempurnakan dan didayagunakan. Hal ini juga akan mendorong golongan nasionalis sekuler dan non-Muslim untuk menyumbangkan pemikiran terbaiknya untuk hal yang sama. Agaknya, Islam pasca Habibie sampai era
Susilo Bambang Yudhoyono (SBY), memiliki masalah dan kesempatan untuk membangun kembali negara bangsa sesuai cita-cita proklamasi 1945 dengan konstitusinya yang juga dijiwai dan diinspirasikan oleh ajaran Islam.

Tidak ada "sebab yang tunggal" dari gejala merebaknya gerakan kaum skripturalis Islam dan Marxis belakangan ini, sebab sejarah kita menunjukkan jejaknya: makin kuat kebangkitan Islamisme, semakin kuat pula kemunculan Marxisme dan Nasionalisme. Akar historis dari satu guru tiga ideologi, di manaH.O.S Tjokroaminoto sebagai guru, dengan tiga murid yang memiliki ideologi berbeda yakni S.M. Kartosoewirjo (Islamis), Soekarno (Nasionalis) dan MusoSemaun (Marxis), memperlihatkan karakter, orientasi ideologi dan model pergerakan yang beraneka ragam. Ekspresi satu guru tiga ideologi itu merefleksikan betapa dalamnya pengaruh Islam, Nasionalisme dan Marxisme di dalam sejarah kaum pergerakan Indonesia. Pengaruh ideologi dan sosialnya di kalangan rakyat masih terasa sampai milenium ketiga ini.

Kini, di tengah euphoria reformasi, bangkit sudah Islamisme, Nasionalisme dan Marxisme. Dan yang menyedihkan: krisis ekonomi pada tingkat global dan nasional, menindas gerakan Islamis, Nasionalis dan Marxis tanpa satupun dari mereka sanggup dan digdaya untuk mengatasinya secara konseptual maupun praksis. Kita melihat, intelektual dan elite Islam, nasionalis maupun Marxis kini kebingungan, gamang dan bahkan "beku" untuk menyeret Indonesia keluar dari multi krisis yang membelenggu. Kepemimpinan nasional era Habibie, Abdurrahman Wahid, Megawati, dan Susilo Bambang Yudhoyono (SBY) belum berhasil secara mendasar dalam memecahkan masalah Ambon-Maluku, Aceh, Papua (Irian jaya) dan lain-lain, serta belum mampu memberdayakan masyarakat bawah yang sangat terpukul oleh badai krisis ekonomi 1997/98. Yang terjadi kemudian para elite nasional kita itu terkesan tidak kompak, tersangkut conflict of interest, gamang dan 
masih mencari-cari solusi terhadap berbagai krisis dan keterpurukan ekonomi-politik dewasa ini.

Akibatnya, di lapisan kaum muda pergerakan, apakah itu sayap Islamis, Nasionalis maupun Marxis, terjadi upaya mencari tafsir, perspektif dan tindakan sendiri-sendiri dalam menghadapi masalah sosial-ekonomi dan politik yang mendesak nurani. Publik belum lupa bahwa pasca jatuhnya Orba Soeharto , munculnya demodemo kaum Islamis dan gerakan aktivis yang berkarakter Marxis, kedua tipologi gerakan yang berbeda ideologi, telah membangkitkan spirit gerakan kaum nasionalis radikal, sehingga persaingan kaum Islam skripturalis, Nasionalis dan Marxis semakin mengental, meskipun tidak semuanya tampak menonjol di permukaan.

\section{SIMPULAN}

Gerakan Islamisme (Salafi radikal, Islam transnasional, terorisme dan ormas Islam garis keras sejenisnya seperti Front Pembela Islam dan Majelis Mujahidin Indonesia, Hizbut Tahrir Indonesia, dan lain-lain) untuk sebagian disebabkan oleh kekecewaan atas merajalelanya korupsi, oligarkisme, ketidakadilan dan keterpurukan ummat secara politik-ekonomi, serta lemahnya negara dan penegakan hukum/rule of law di Indonesia. Golok dan pedang yang disandang adalah refleksi kurangnya kepercayaan pada negosiasi, diplomasi dan cara-cara moral-etis pemerintahan pimpinan SBY yang sedang belajar menata diri. Untuk sebagian juga hal itu disebabkan berdirinya organisasi kemasyarakatan dan cendekiawan yang berbasis agama telah menambah kesan bahwa agama identik dengan alat tukar dalam politik. Artinya, agama lebih dikonotasikan sebagai alat tukar dalam politik, seperti barang 'mati' yang bisa dijadikan obyek untuk politik dagang sapi.

Dalam konteks ini, perang wacana (heteroglossia, meminjam wacana Mikhail Bakhtin, inteligensia Rusia) di kancah blantika politik Indonesia antara aliran ke-Islaman, Kebangsaan dan ke-Kirian, yang semestinya dilakukan dengan cara terpelajar atau intelektual, pada gilirannya jatuh ke dalam perang wacana yang vulgar, politik massa (mass politics) dan bernuansa antagonistisideologis. Ideologi Islamisme, Nasionalisme dan Marxisme mengalami reifikasi, penggerusan makna, sekedar sebagai gerakan politik yang berorientasi kekuasaan, bukan humanisasi dan pencerahan akal budi di kalangan pengikut ketiga aliran politik itu sendiri. Dalam hal ini, kombinasi yang buruk dari demokratisasi dan keterpurukan ekonomi masyarakat bawah akan membuka peluang bagi apa yang disebut Gustave le Bon dan Karen Armstrong sebagai bangkitnya kekuatan-kekuatan religius dan fundamentalis. Dalam konteks Indonesia, situasi itu juga membuka ruang bagi gerakan nasionalis kiri/Marxis dan separatisme. Inilah pekerjaan tambahan bagi pemerintah dewasa ini, apapun taruhannya.

Dengan melihat maraknya gejala separatisme dan kekerasan di Maluku, Aceh, Irian Jaya dan seterusnya, akhirnya, semua terpulang kepada para intelektual, politikus dan angkatan muda Islam yang punya komitmen pada kehidupan berbangsa bernegara. Apakah mereka akan mengambil kesempatan ataukah hanya menunggu datangnya persoalan? Akhirakhir ini di bawah kepemimpinan Presiden Susilo Bambang Yudhoyono, radikalisme, sektarianisme, terorisme, separatisme dan arus semacam tipologi gerakan itu pada satu sisi dengan jelas menyiratkan sisi gelap modernisme dan demokrasi, namun di sisi lain bisa makin memperkuat kewaspadaan, koreksi dan instrospeksi serta inovasi agar bangsa kita bebas dari ancaman kekerasan dan ketimpangan, rasa cemas dan ngeri.

Pada tahun-tahun terakhir abad 21 ini, di Tanah Air kasus serangan atas jemaah Ahmadiyah di Cikesik, Muslim Syiah di Madura dan aksi terorisme di Solo, Medan, Jakarta, Cirebon, juga aksi kekerasan Organisasi Papua Merdeka (OPM) di Papua, RMS di Maluku dan seterusnya, menunjukkan maraknya radikalisme, sektarianisme, terorisme dan separatisme, yang seakan 
berhimpitan dan tumpang tindih. Sayangnya, para politisi, pemimpin dan elite penguasa nampak tidak begitu perduli dan tidak cukup memahami bahwa kecemasan dan kengerian rakyat atas carut-marut demokrasi liberal belakangan ini adalah awal dari disorientasi dan disilusi. Karenaitu, semestinya negara dan civil society harus cepat berusaha menemukan hakekat reformasi dan demokratisasi itu kembali dalam upaya memperkuat nation and character building masa kini dan masa depan agar Indonesia tidak luruh di tengah arus globalisasi.

\section{DAFTAR PUSTAKA}

Ahmed, A.S., 1993, Postmodernisme: Bahaya dan Harapan Bagi Islam, Bandung: Mizan.

Azhary, M. T., 1992, Negara Hukum: Suatu Studi tentang Prinsip-prinsipnya Dilihat dari Segi Hukum Islam, Implementasinya pada Periode Negara Madinah dan Masa kini, Jakarta: Bulan Bintang.

Djalal, H, 1999, “Debat Otonomi Daerah dan Negara Federasi" dalam Republika, Selasa 21 Desember 1999.

Feith, H, and Castles, L., (eds.), Pemikiran Politik Indonesia 1945-1965, terjemahan Hasan Basari, Jakarta: LP3ES, 1988.

Ohmae, K, 1997, "Year of Transition," In Asiaweek.

Koentjaraningrat, 1991, “Kepemimpinan dan Kekuasaan" dalam Miriam Budiardjo (Ed.), Aneka Pemikiran Tentang Kuasa Dan Wibawa, Jakarta: Sinar Harapan.

Mallarangeng, A. A., dan Rasyid R., (ed.), 1999, "Otonomi dan Federalisme" dalam Federalisme untuk Indonesia, Jakarta: Kompas.

Noer, D, 1978, Pemikiran Politik di Negeri Barat, Jakarta: Rajawali.

Khaldun, I, 1965, Masyarakat dan Negara, Terjemah Osman Raliby, Jakarta: Bulan Bintang.
Husaini, S.WA., 1983, Sistem Pembinaan Masyarakat Islam, Judul Asli: Islamic Environmental System Engineering, Terjemahan Anas Mahyuddin, Bandung: Pustaka Salman.

Johns, A.H., 1981, "Political Authority in Islam: Some Reflections Relevant to Indonesia" dalam

Al-Mubarak, M, 1995, Sistem Pemerintahan dalam Perspektif Islam, Solo: Pustaka Mantiq.

Suseno, F.M., 1987, Etika Politik, Jakarta: Gramedia.

Garaudy, R, 1982, Janji-janji Islam, Terjemahan H.M. Rasjidi, Jakarta: Bulan Bintang.

Kartakusuma, T.I. Yojana, 2001, “Konstitusi Baru di Abad 21: Rekonstruksi Integral Sistem Politik Baru Demokratis di Indonesia" dalam Makalah Seminar Sehari: "Reposisi Lembaga Tinggi/Lembaga Negara dalam Konteks Amandemen UUD 45" Indonesia Democracy Monitor, Jakarta, Rabu 28 Maret 2001.

Kerr, M.H., 1996, Islamic Reform: Political and Legal Theories of Muhammad Abduh and Rashid Ridha, Berkeley and Los Angeles: University of California Press.

Kuntowijoyo, 1991, Paradigma Islam: Intepretasi untuk Aksi, Bandung: Mizan.

Kompas, 1999, "Sosialisasi tentang Federalisme dan Negara Federal," Kompas, Sabtu 20 November 1999.

Le Bon, G, 2000, The Psychology of Revolution, Germany: Guttenberb Project.

Jurnal Pasar Modal Indonesia, Januari 2000.

Reid, A, (ed.), 1993 “The Making of an Islamic Political Discourse in Southeast Asia," Monash Paper on Southeast Asia, 27 (12).

Reid, A, dan Marr, D., 1981, Perception of the Past in the Southeast Asia, Singapore: Heinemann (Asia) Ltd. 
Rosenthal, E.I.J, 1958, Political Thaut in Medieval Islam: An Introductory Outline, Cambridge: Cambrigde University Press.

Roy, O, 1994. The Failure of Political Islam, Cambridge, Mass.: Harvard University Press.

Sastrapratedja, M, 1981, "Pancasila adalah Etika Politik". Harian Kompas, 8 Mei 1981.

Sasongko, H, 1999, Pancasila Kendaraan Politik dari Masa ke Masa, Depok: Pustaka Grafiksi.

Suseno, F.M., 1987, Etika Politik, Jakarta: Gramedia.
Sopingi, 1999, Republik Kesatuan di Persimpangan Jalan, Depok: Pustaka Grafiksi.

Tibbi, B, 2001. Islam between Culture and Politics. New York, NY: Palgrave. 2012. Islamism and Islam. Connecticut: Yale University Press.

Thurow, L.C., 2012, The Future of Capitalism in http/ / Amazon.com

van Niel, R, 1984, The Emergence of the Modern Indonesian Elite, Holland: Koninklijk Instituut voor Taal, Landen Volkenkunde, Foris Publications, Holland. 